\title{
Desalination in Spain. Past, present and future
}

\author{
E. CABRERA ${ }^{1}$, T. ESTRELA ${ }^{1,2}$, J. LORA ${ }^{1}$
}

\author{
${ }^{1}$ Universitat Politècnica de València. Spain \\ ${ }^{2}$ Jucar River Basin Authority of Spanish Ministry for Ecological Transition, Valencia, Spain
}

\begin{abstract}
A summary of the evolution of desalination in Spain, spanning over half a century of history, follows. What started as a solution to resolve occasional water shortages in islands where natural surface and ground water resources were scarce, has gained more relevance with technological advancements, less expensive production costs and at the same time minimizing the impact on the environment. But fifteen years ago, the normal pace of history underwent an about-turn with the sudden construction of a significant number of desalination plants. The speed, and on occasions the haste, involved in many of the decisions, brought about some imbalance between the different players that were involved. Time, and above all, technological advancement have clarified the situation, and most of the desalination plants that were built have managed to find their place, thus justifying the investment that was made. But there are still some stages to address, particularly that of integrating these plants in the joint water resource operation systems. In this regard, consumers must accept that desalination plants competing with traditional water resources, greatly improve the guarantee of supply, and in fact act as a new water insurance that, indeed, has a cost. Today however, and particularly in the future, desalination in Spain plays and will continue to play an essential role, especially in the southeast Mediterranean region and in some of the more touristic islands. The following is a brief history.
\end{abstract}

\section{Dessalement en Espagne. passé, présent et futur}

RÉSUMÉ. - Ce qui suit est un résumé de l'évolution du dessalement en Espagne, couvrant plus d'un demi-siècle d'histoire. Ce qui a commencé comme une solution pour résoudre les pénuries d'eau occasionnelles dans les îles où les ressources naturelles en eaux de surface et souterraines étaient rares, a gagné en pertinence avec les progrès technologiques, en réduisant les coûts de production et en minimisant l'impact sur l'environnement. Mais il y a quinze ans, le rythme normal de l'histoire s'est inversé avec la construction soudaine d'un nombre important d'usines de dessalement. La rapidité, et parfois la précipitation, impliquée dans de nombreuses décisions, a entraîné un déséquilibre entre les différents acteurs impliqués. Le temps et surtout les progrès technologiques ont clarifié la situation et la plupart des usines de dessalement construites ont réussi à trouver leur place, justifiant ainsi l'investissement réalisé. Mais il reste encore des étapes à franchir, notamment celle de l'intégration de ces installations dans les systèmes communs d'exploitation des ressources en eau. À cet égard, les consommateurs doivent accepter que les usines de dessalement en concurrence avec les ressources en eau traditionnelles améliorent considérablement la garantie d'approvisionnement et constituent en fait une nouvelle assurance de l'eau qui a effectivement un coût. Mais aujourd'hui et surtout à l'avenir, le dessalement en Espagne joue et continuera à jouer un rôle essentiel, en particulier dans la région sud-est de la Méditerranée et dans certaines des îles les plus touristiques. Ce qui suit est une brève histoire.

\section{THE AWAKENING OF DESALINATION IN SPAIN}

Desalination has been around for over half a century in Spain, and has come a fairly long way since then. In relation to the historical development of desalination, an excellent description about the evolution of processes and technologies can be found in Torres (2008). Based on that reference, we shall now summarize some of the most important milestones since the first plant was built in Lanzarote (Canary Islands) in 1964. It was a private initiative with the aim of improving conditions on the island to encourage tourism. It had a fairly modest production capacity $\left(2000 \mathrm{~m}^{3} /\right.$ day $)$ with an energy intensity that would be unaffordable today (over $50 \mathrm{kWh} \mathrm{m}^{3}$ ). The plant featured technology based on an evaporation process.

The success of the Lanzarote plant encouraged some of the drier neighbouring islands, specifically Fuerteventura and Gran Canaria, and also the city of Ceuta which saw desalination as a solution to becoming self-sufficient in view of its isolated location and water supply problems. Hence, at the turn of the seventies construction of these new plants began almost simultaneously, driven by the Public Administration. Their production capacities were still somewhat modest (Ceuta, $4000 \mathrm{~m}^{3} /$ day, Fuerteventura $4000 \mathrm{~m}^{3} /$ day), except in the case of Gran Canaria, which produced $20,000 \mathrm{~m}^{3} /$ day. All these plants were operating at the start of the 1970's. In view of the success of the pioneer plant on Lanzarote, it soon increased its capacity to $5000 \mathrm{~m}^{3} /$ day. The process was always the same: distillation. In the second half of the decade, with all these plants operating and having proven their reliability, the Canary Islands tourism sector saw desalination as a solution to the problems inhibiting growth, and consequently the three eastern-most islands, the driest ones, began construction on their second plants at the same time.

This took place during the years following the first oil crisis. The cost of energy weighed heavily on them, and although the plants had become considerably more efficient, with energy consumption having been reduced by half by 1980 $\left(25 \mathrm{kWh} / \mathrm{m}^{3}\right)$, the solution could only be justified if there was no other solution, or if there was a power station nearby that 
could supply hot water at a very low cost. And so the first desalination on mainland Spain was built in Almeria, one of the driest regions in the country, namely the Carboneras Plant, adjacent to the thermal power station of the same name. With a somewhat modest capacity $\left(2200 \mathrm{~m}^{3} /\right.$ day $)$, it began operating in 1980. But it was short-lived because the days of evaporation, the standard process used until then, were numbered. During the early years of that decade the reverse osmosis process (RO) would appear in force, and since then, with only a few exceptions when brackish water is the source and electrodialysis can be used, this is the process most widely implemented.

In the following twenty years (the eighties and nineties) there were few notable changes. RO was implemented as a general rule, and construction of new desalination plants continued at a steady but slow rate. Three more in the eastern Canary Islands and then desalination in the drier Balearic Islands began, Ibiza in 1995 and Majorca in 1998. New plants were also built at specific points along the Mediterranean coastline, when the urban water supply was threatened during the severe periods of drought between 1992 and 1995. More specifically in Malaga and Almeria. Construction of new plants to desalinate brackish water also began during that period, using fresh water with a much lower salt content. The Denia desalination plant was built in 1990 , with production capacity of $16,000 \mathrm{~m}^{3} /$ day, fed by water from a nearby river. The salt concentrations of brackish water vary greatly. The wide range between the upper limit of fresh water (from $0.5 \mathrm{~g} / \mathrm{l}$ ) and the lower limit of seawater $(35 \mathrm{~g} / \mathrm{l})$, which reaches its highest values in the Dead Sea $(350 \mathrm{~g} / \mathrm{l})$ must be mentioned at this point. Obviously the possibility of desalinating fresh water has two advantages. The lower cost of desalination and the possibility of building plants away from the coastline.

Agriculture was not alien to this awakening either. On the one hand, the costs of desalinating brackish water are considerably lower than seawater, and on the other, certain soils and crops have greater tolerance to salinity. This subject has been researched in depth in agricultural engineering. In terms of salinity, it is estimated that good quality water is when salinity is below $0.77 \mathrm{~g} / \mathrm{l}$, average quality between the latter and $2.24 \mathrm{~g} / 1$ and poor quality when values are any higher than this (Ruiz, 2005). It is hardly surprising therefore, that after the 1992 - 95 drought, high added value agriculture in the southeast Mediterranean (Alicante, Murcia and Almeria) wanted to improve the guarantee of their irrigation water supply. It is estimated (Zarzo, et al., 2013) that between 1995 and 2000 over 200 desalination plants were built with production capacities between $500 \mathrm{~m}^{3} /$ day and $10,000 \mathrm{~m}^{3} /$ day.

This chain of events, with a gradual and continued growth of desalination, building new plants at key points, underwent a sudden change in speed in March 2004. Let us take a look at the chain of events.

\section{THE TURNING POINT OF DESALINATION}

In July 2001 the National Hydrological Plan Act was passed (BOE, 2001) and the Popular Party Government decided to carry out the main action defined in the said Act, the Ebro Diversion. The preparations to carry out this huge project began with two lines of action: technical / economic and financial. The second line, based on European development funding, was very significant at that time. However, this decision led to strong tension in the country's water policies, with mass demonstrations in favour and against the diversion.

In spring 2004 there was a change of government after the victory by the Socialist Party and the first decision by the new government concerning water policy was to repeal the diversion, also leading to tension between regions (BOE, 2004). Moreover, this meant that the secured European funding had to be used for another purpose. It was a quick, simple decision, part of the funds was assigned to construction of desalination plants, which materialized in the Global Action Program for Management and Use of Water (A.G.U.A. according to the Spanish acronym), (Figure 1) which was implemented over the two terms of Socialist rule (2004 to 2011). Construction of a large number of desalination plants began along the Mediterranean coast, with varied capacities, ranging from $80 \mathrm{hm}^{3} /$ year in Torrevieja (Alicante), to $3.5 \mathrm{hm}^{3} /$ year in Ciudadela (Menorca, Balearic Islands). The investment was considerable - €2000 million.

Supporters of the Ebro Diversion severely criticized the AGUA Program desalination plants. Their main argument was the high-energy consumption of these plants, since jointly they would account for $1 \%$ of the total energy consumption of Spain. It is not surprising then that, right from the start, the main efforts concerning development of desalination focused on reducing its energy intensity. And although significant progress has been made, it is still relatively high.

Due to this turbulent water policy, growth was rather abnormal. Not so much in terms of desalination plants planning, but more concerning the complementary infrastructures required. Indeed, the biggest of them, Torrevieja, was built without a sufficient electricity supply (the required power exceeds 60 Mw) which by the end of 2018 had still not been completed. The smallest, Ciudadela, in the northeast of the island of Menorca, was built without finishing the pipeline to connect it to the main consumption point, the city of Mahon in the southeast of the island, which is actually supplied by ground water with high nitrate concentrations. And those that have not had operating problems, such as Barcelona, only occasionally work at full capacity owing to the very high operating costs. It is required in case of drought, and therefore it is fundamental to include it as a complementary source of supply in the integrated water resource system.

Time continues to prove the important role of desalination plants to tackle water shortages in arid territories, as the effects of climate change only serve to worsen this situation. But, during the years of the construction boom (early years of this century), there was an over-estimation of the need for water. Therefore most of the plants were over-sized making it difficult to fully integrate them in the system.

\section{THE CURRENT SOCIO-ECONOMIC / ENVIRONMENTAL CONTEXT}

As mentioned previously, the urgency to make a major investment in a short period of time hindered proper planning for such an ambitious Plan. But that was not the main impediment that these new desalination plants have had to overcome. The other problem was the price difference between energy and water. Whereas in Spain the cost of energy is fully recovered (even including some taxes), that is not the 


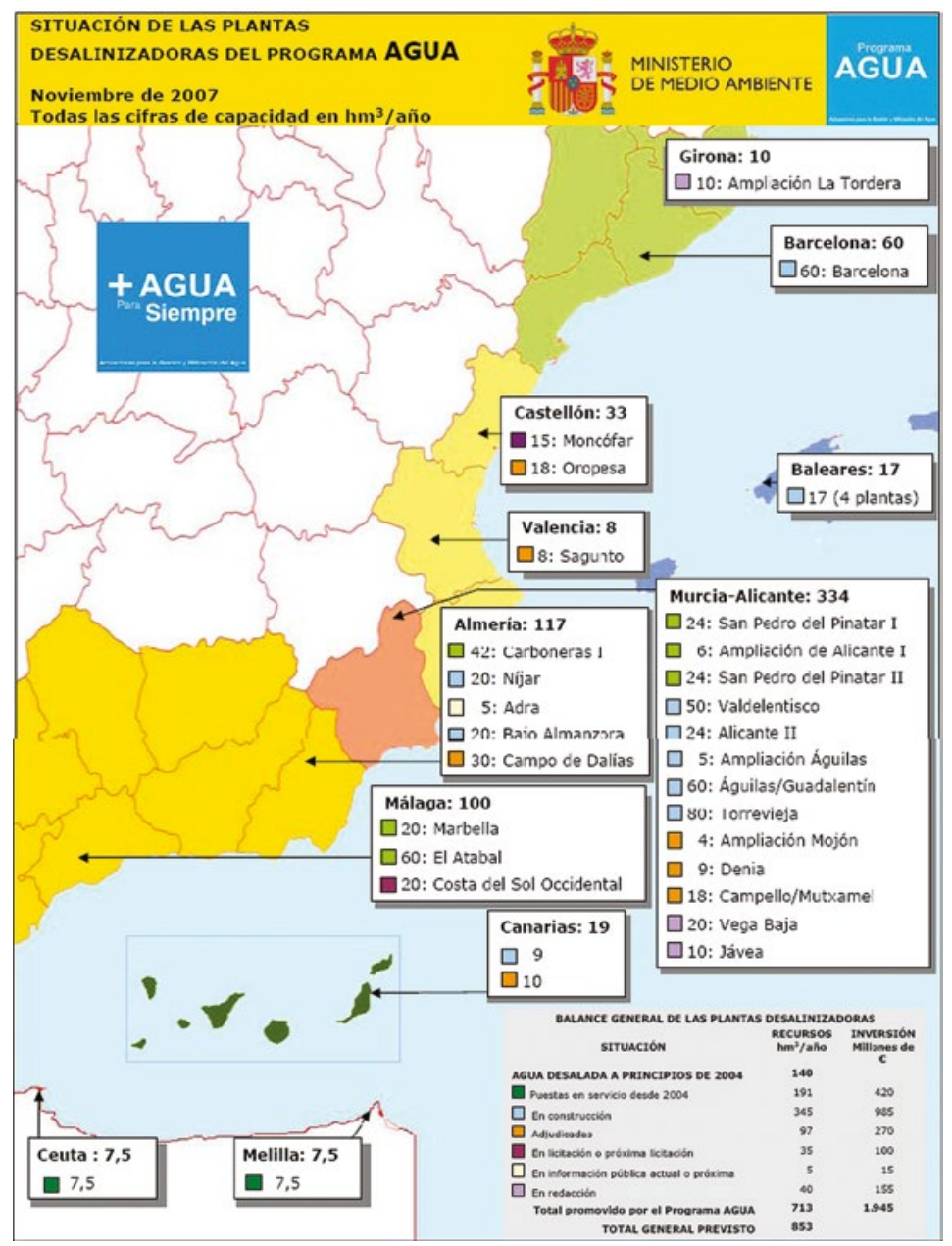

Figure 1 : The AGUA Program (Araus, 2007).

case with water. And since the price of desalinated water is dependent on the price of energy, there is no fair competition with traditional water sources. Figure 2, which compares prices in Europe of these two resources, proves this. While in terms of energy prices, Spain is in the first positions, the price of water is at the bottom of the list. Furthermore it must be underlined that Figure 2 refers to urban water prices. Irrigation water is, by far, cheaper. Consequently, irrigating with desalinated water is only viable for farmers who produce high added value crops. It is therefore logical that the Spanish Desalination and Re-utilization Association (AEDyR) complain about this somewhat unfair competition (Cala, 2013).

Water prices in Spain for public water supply are politicized and those responsible for management will only commit to complete cost recovery when there is no other option. While citizens accept they must pay their taxes and the real costs of energy, this is not the case in the cost of water services, although they accept paying costs hundreds and sometimes thousands of times higher for bottled water. There is therefore an evident lack of environmental education. But the future of desalination is promising, since most of the factors conditioning it are aligning in its favour. These include the following:

a) The idea of diversions is being side-lined. Without a large consensus it is barely viable today, and without European funds the infrastructure does not appear affordable. This calls for the need for desalination plants and reuse waters in semi-arid and coastal regions to complement the available resources and thus facilitate restructuring of the utilized water resources.

b) More specifically, climate change and the resulting depletion of natural resources this entails, mean a new integrated water resources management framework is required.

c) Desalination plants are local infrastructures that do not require such wide consensus.

d) Without European funds to finance new infrastructures or replace the existing ones, it will be necessary to progress in this area in full application of the principle of cost recovery (Cabrera et al., 2013).

e) As mentioned, there are some cases where complementary works are missing, but the main infrastructure is already in place. Within that framework, the things remaining to be done are more affordable.

f) The constant technological advancements also help to a very large extent.

\section{DESALINATION AS A SUPPLY GUARANTEE}

Management of water resources in the 21 st century is a far cry from what it was last century. The current water resources, and particularly the future ones face the challenge of compatibility of water usage and protection of the environment through sustainable management of resources, in which conservation, awareness and social participation, environmental education, demand management policies and 

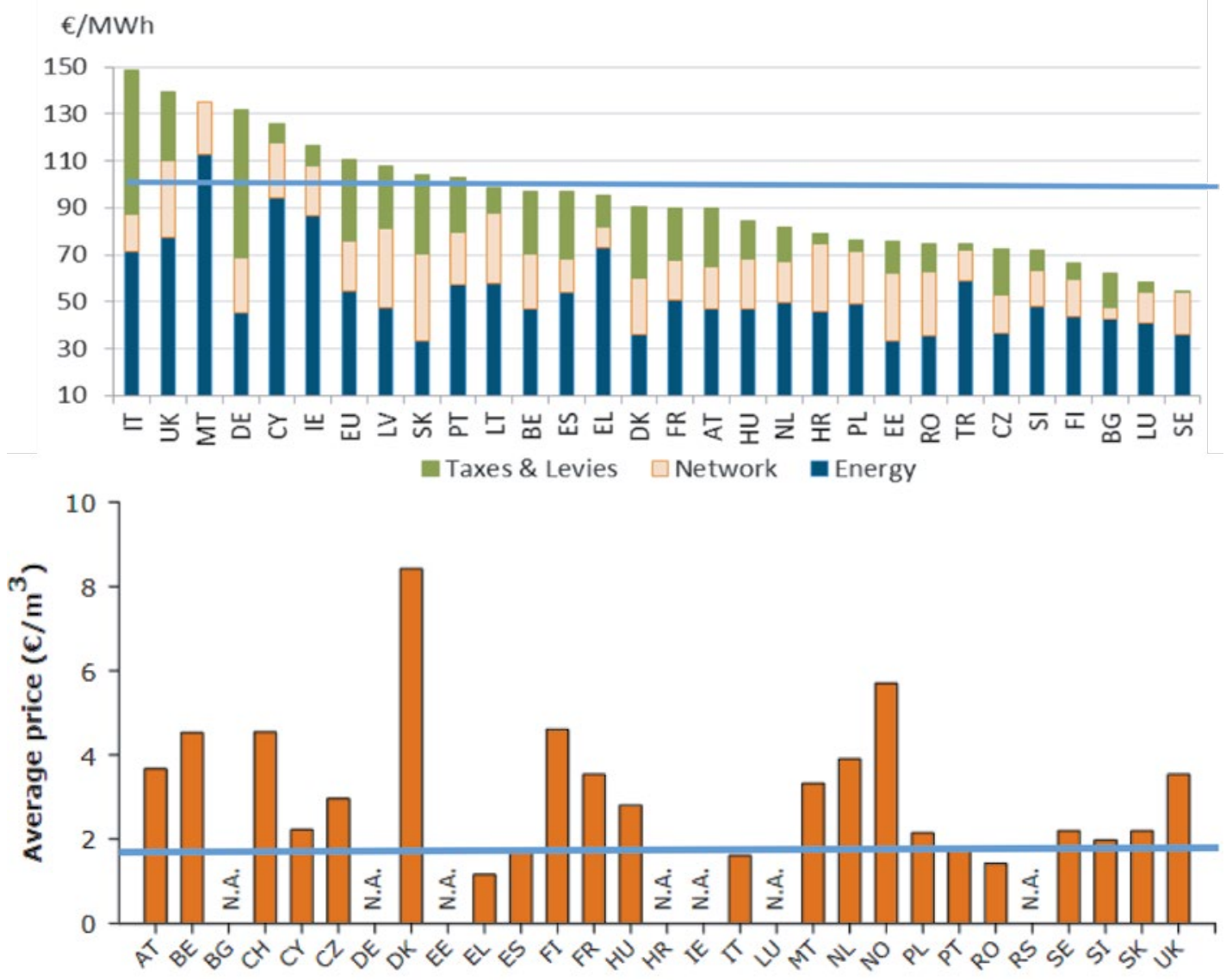

Figure 2 : Energy (EC, 2016) and water (EurEau,2017) prices in Europe.

the use of non-conventional resources such as desalination or re-utilization are increasingly called for.

On the one hand, the trend in Spain over recent years has been characterized by a gradual increase in water shortage, which has been worsened by some negative predictions concerning climate change on water resources. The results of the IPCC's 5th Assessment Report confirm the forecasts on a reduction in natural contributions. A more detailed analysis forecasts a reduction in run-off water that will vary between $20 \%$ and $40 \%$ in the different river basin districts in Spain by the end of the century (CEH, 2017). On the other hand, the report forecasts that droughts in Spain will become more frequent. Moreover, competition between agriculture, industry and populations for the scarce available water resources could restrict development activities and further aggravate existing conflicts. Planned, sustainable management of all available resources, guaranteeing environmental protection, is a priority objective today.

It could be claimed that surface water resources in Spain today are practically fully regulated, particularly in the regions more vulnerable to shortages and drought, and therefore construction of a significant number of new reservoirs is not expected. On the other hand, ground water resources in aquifers in more arid regions are highly exploited, in some cases leading to an unsustainable situation due to more extraction of water than natural recharge. No significant increase in ground water wells is expected either. Consequently, in regions with more fragile balances, demand management and the utilization of non-conventional resources must play a significant role, such as reusing treated wastewater or desalinating brackish or seawater. Desalination provides the right amount of quality water. It is a key resource in extreme situations and significantly increases the guarantee of water
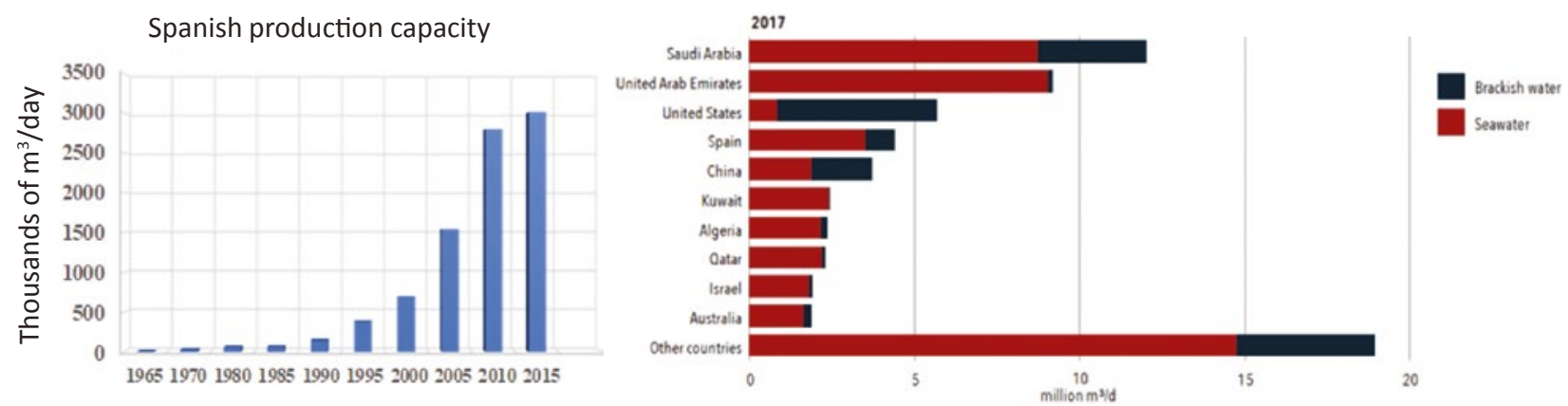

Figure 3 : Desalinated production capacity in Spain and in the world in 2017 (Zarzuela, 2018). 
demand, particularly in urban water supplies. After a past full of ups and downs, desalination has a promising future.

\section{THE CURRENT ROLE OF DESALINATED WATER IN SPAIN.}

The production capacity of desalinated water in Spain is around $1000 \mathrm{hm}^{3} /$ year (Figure 3). The high number of plants built in the last 25 years, nearly all of them within the mentioned AGUA Program (Figure 1), has brought about significant developments in the desalination industry, with a high technological capability.

For the reasons described earlier, actual desalinated water production is below production capacity, and accounts for $1 \%$ $2 \%$ of the actual water demand. Details can be seen in Table 1.

Table 1 clearly shows the huge differences between the Spanish river basin districts. From a total (or quasi total) urban water desalination dependency (Melilla, Ceuta, Segura and Canary Islands) to almost no dependency (Jucar and Inland Basins of Catalonia -Barcelona area-) through moderate dependency (Balearic Islands, Andalusian Mediterranean basins). Indeed, in most of the regions, traditional water resources are the only water sources. In any case, according to forecasts included in the new hydrological basin plans for the 2016-2021 cycle, they will play a more relevant role in the near future.

Unlike what is happening in the world, desalination is not a newcomer in Spanish agriculture. It consumes $22 \%$ of the total desalinated water, whereas in the rest of the world it does not exceed 3\% (Zarzo, 2017). It is used in areas with low availability of conventional resources, but where there is highly productive irrigated agriculture. The energy intensity of brackish water desalination is $1-1.5 \mathrm{kWh} / \mathrm{m}^{3}$, similar to pumping from over-exploited aquifers where the water table is between $250 \mathrm{~m}$ and $400 \mathrm{~m}$ deep. That is to say, brackish water is energetically competitive from depths of $250 \mathrm{~m}$ and deeper.

\section{COSTS OF DESALINATED WATER IN SPAIN}

Except in cases of extreme necessity, to a large extent final desalination implementation depends on its costs. Since these costs are highly dependent on the size of the plant and its workload, final success is still somewhat complex. The Administration sometimes helps with setting up these plants by partially subsidizing these costs, and this problem will be overcome as plants start working at full production capacity. Indeed, a detailed cost analysis of seven large seawater desalination plants (RO process), located in Murcia and Alicante with uniform cost recovery criteria concludes that these costs range from $€ 0.63 / \mathrm{m}^{3}$ to $€ 0.72 / \mathrm{m}^{3}$, providing they operate at full capacity (Lapuente, 2012). At partial load, these costs increases dramatically. On the other hand, Figure 4 shows the cost variation (capital, operation and maintenance) with the volume produced, based on data from plants built by Acuamed in recent years, calculated by the Júcar River Basin Authority. As can be seen, produced water costs range between $€ 0.45$ and $€ 0.55 / \mathrm{m}^{3}$ for plants operating at full capacity, in tune with previous works (Lapuente, 2012).

Table 1 : Desalinated water today in the Spanish River basin districts (2012-2015).

\begin{tabular}{|l|c|c|c|c|c|}
\hline River Basin District & $\begin{array}{c}\text { Total water } \\
\text { demand } \\
\left(\mathrm{hm}^{3} / \text { year }\right)\end{array}$ & $\begin{array}{c}\text { Water } \\
\text { demand } \\
\text { (urban use) }\end{array}$ & $\begin{array}{c}\text { Desalination } \\
\text { resources }\left(\mathrm{hm}^{3} /\right. \\
\text { year })\end{array}$ & $\begin{array}{c}\text { Percentage } \\
\text { desalination of } \\
\text { demand }\end{array}$ & $\begin{array}{c}\text { Percentage desalina- } \\
\text { tion of demand for } \\
\text { urban use }\end{array}$ \\
\hline Eastern Cantabria & 273 & 234 & 0 & $0.0 \%$ & $0.0 \%$ \\
\hline Western Cantabria & 462 & 180 & 0 & $0.0 \%$ & $0.0 \%$ \\
\hline Galicia Coast & 369 & 226 & 0 & $0.0 \%$ & $0.0 \%$ \\
\hline Miño-Sil & 439 & 102 & 0 & $0.0 \%$ & $0.0 \%$ \\
\hline Duoro & 3,758 & 287 & 0 & $0.0 \%$ & $0.0 \%$ \\
\hline Tajo & 2,713 & 741 & 0 & $0.0 \%$ & $0.0 \%$ \\
\hline Guadiana & 2,130 & 166 & 0 & $0.0 \%$ & $0.0 \%$ \\
\hline Tinto, Odiel and Piedras & 309 & 66 & 0 & $0.0 \%$ & $0.0 \%$ \\
\hline Guadalquivir & 3,798 & 379 & 0 & $0.0 \%$ & $0.0 \%$ \\
\hline Guadalete and Barbate & 438 & 108 & 0 & $0.0 \%$ & $0.0 \%$ \\
\hline Andalusian Mediterranean Basins & 1,393 & 345 & 43.6 & $3.1 \%$ & $12.6 \%$ \\
\hline Segura & 1,693 & 186 & 159.3 & $9.4 \%$ & $85.6 \%$ \\
\hline Júcar & 3,241 & 525 & 3.50 & $0.1 \%$ & $0.7 \%$ \\
\hline Ebro & 8,334 & 359 & 0 & $0.0 \%$ & $0.0 \%$ \\
\hline Inland Basins of Catalonia & 1,046 & 572 & 16.7 & $1.6 \%$ & $2.9 \%$ \\
\hline Balearic Islands & 253 & 139 & 28.1 & $11.1 \%$ & $20.2 \%$ \\
\hline Melilla & 11 & 7 & 7.6 & $69.1 \%$ & $108.6 \%$ \\
\hline Ceuta & 9 & 7 & 7.0 & $77.8 \%$ & $100.0 \%$ \\
\hline Canary Islands & $\mathbf{3 1 , 1 2 3}$ & $\mathbf{4 , 8 4 2}$ & $\mathbf{3 9 4 . 7}$ & $1.3 \%$ & $60.2 \%$ \\
\hline TOTAL & & & & $8.2 \%$ \\
\hline
\end{tabular}




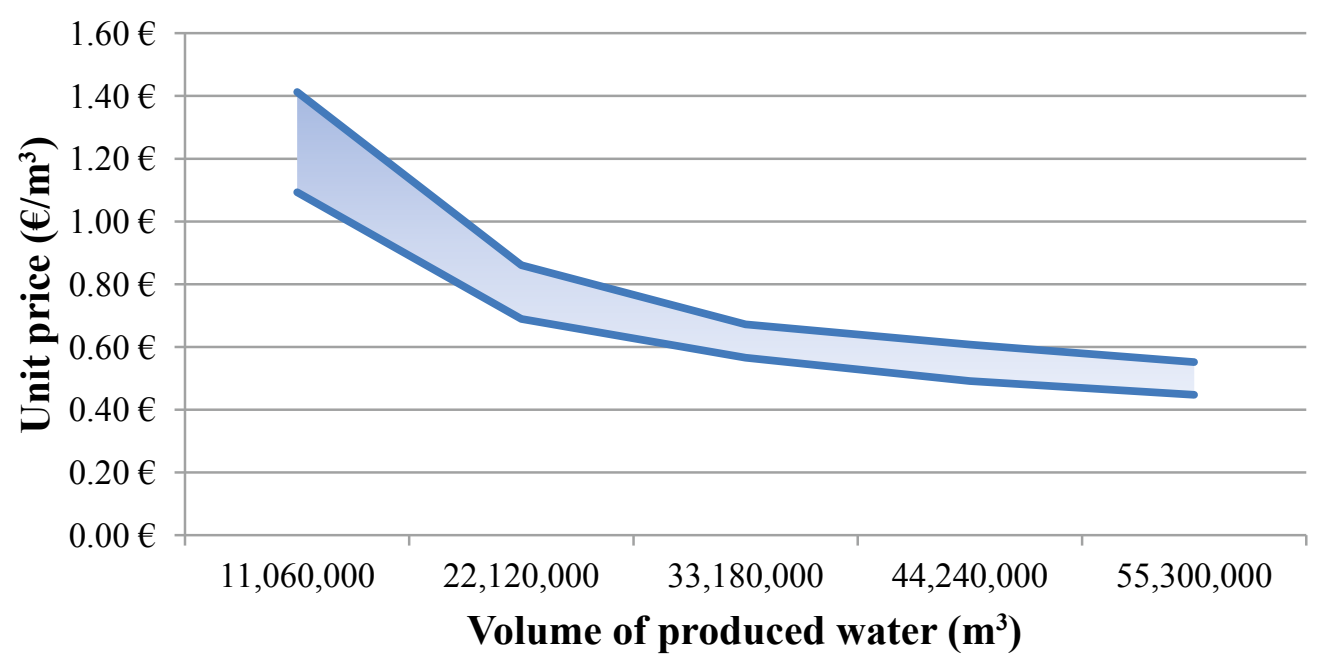

Figure 4 : Desalination costs versus water production. Data from Muchamiel, Sagunto, Oropesa and Moncofar plants.

Nevertheless, and despite the recent reductions in costs, there are still some Desalination Plants underused, particularly in the Region of Valencia. The causes are easy to explain. At the beginning of the century, City Halls saw desalination plants as the solution to ambitious urban and industrial expansion plans, supporting their construction. Sagunto, Moncofa and Oropesa plants (around 100,000 $\mathrm{m}^{3 /}$ day each) were built within that framework. But with the arrival of the economic crisis, the forecasts of an increasing demand failed dramatically, and the City halls withdrew their support. As the municipal elections voting period is every four years, mayors are mainly concerned about short term issues, ignoring that starting up these Plants has notable advantages, albeit in the long-term: a) better water quality in coastal developments where there is high salinity, b) better supply guarantee, diversifying sources and guaranteeing urban and industrial growth and c) contribution to achieving environmental objectives concerning ground water in coastal zones avoiding pumping water from over-exploited aquifers.

Indeed, as water shortage becomes more evident, the desalination plants begin to operate. This is the case of the Mutxamel Plant, at the southern end of the Júcar River Basin District, near Alicante. With a production capacity of $50,000 \mathrm{~m}^{3} /$ day $\left(18 \mathrm{hm}^{3} /\right.$ year), this plant helped overcome a severe period of drought (2015-16) in the Marina Baja area. But after the drought, the Plant is no longer operating, and this should not be the case until the problems of over-exploitation of the aquifers in the Vinalopo River basin, which are used to supply water for agricultural and urban use in the Vinalopo - Alacanti system, have been solved. The discussed advantages (improving supply guarantee, permitting urban and industrial growth and recovering aquifers) widely offset paying a little more for desalinated water. This highlights the need to move towards integration in a joint water resource exploitation system.

\section{THE FUTURE OF DESALINATION IN SPAIN}

In areas where water resources are under great pressure, practically the entire Mediterranean Arch, desalination cannot be ruled out. This is mainly because most urban growth, and therefore population growth, is concentrated around coastal areas. Moreover, desalination plants can be built, in relation to other water infrastructures, in a short period of time, and furthermore, they are local works. Another feature that confers high technical viability of these plants is the fact that they are modular and scalable. The civil engineering is designed for the long-term ( 30 or 40 years) whereas the industrial equipment is designed for the mid-term (15-20 years).

Although the high energy consumption and associated GHG emissions and costs, are problems that these plants will always have, dramatic improvements over recent decades (from $50 \mathrm{kWh} / \mathrm{m}^{3}$ to $3 \mathrm{kWh} / \mathrm{m}^{3}$ today) have changed the future of desalination. This has been possible due to the use of better, selective membranes, more compact treatment designs, the use of highly efficient energy recovery ( $>97 \%$ ), and the greater capacity of the new desalination plants.

The second fact that has traditionally worked against these plants is environmental. But the alleged impact on the marine environment due to seawater collection works and the return of rejected water (brine) to the sea, with possible effects on the sea life at the discharge point (higher local salinity of the seawater), appear to have been overcome. To minimize this problem, some regulated procedures have been established to assess the environmental impact of these plants. When building plants, a set of preventive measures, such as diluting the brine and controlling the discharge of effluent through underwater outlets and monitoring programs during operation must be adopted.

Field tests in island and mainland facilities (Balearic Islands and the Mediterranean Arch) have proved the null environmental impact when collection and discharge are carried out in the right places and plants are properly designed and operated (Urrea, 2007). On the other hand, the Spanish Ministry on Environmental issues, either through its regional bodies or state companies, has driven a set of actions to conserve the Posidonia Oceanica (Neptune Grass) meadows, a seed or flowering plant which is endemic along the Mediterranean coasts. Desalination Plants operate today with maximum respect for this rich habitat, which is vital for many marine species along the Mediterranean coastline. This is the result of work executed by the "Centro de Experimentación y Obras 


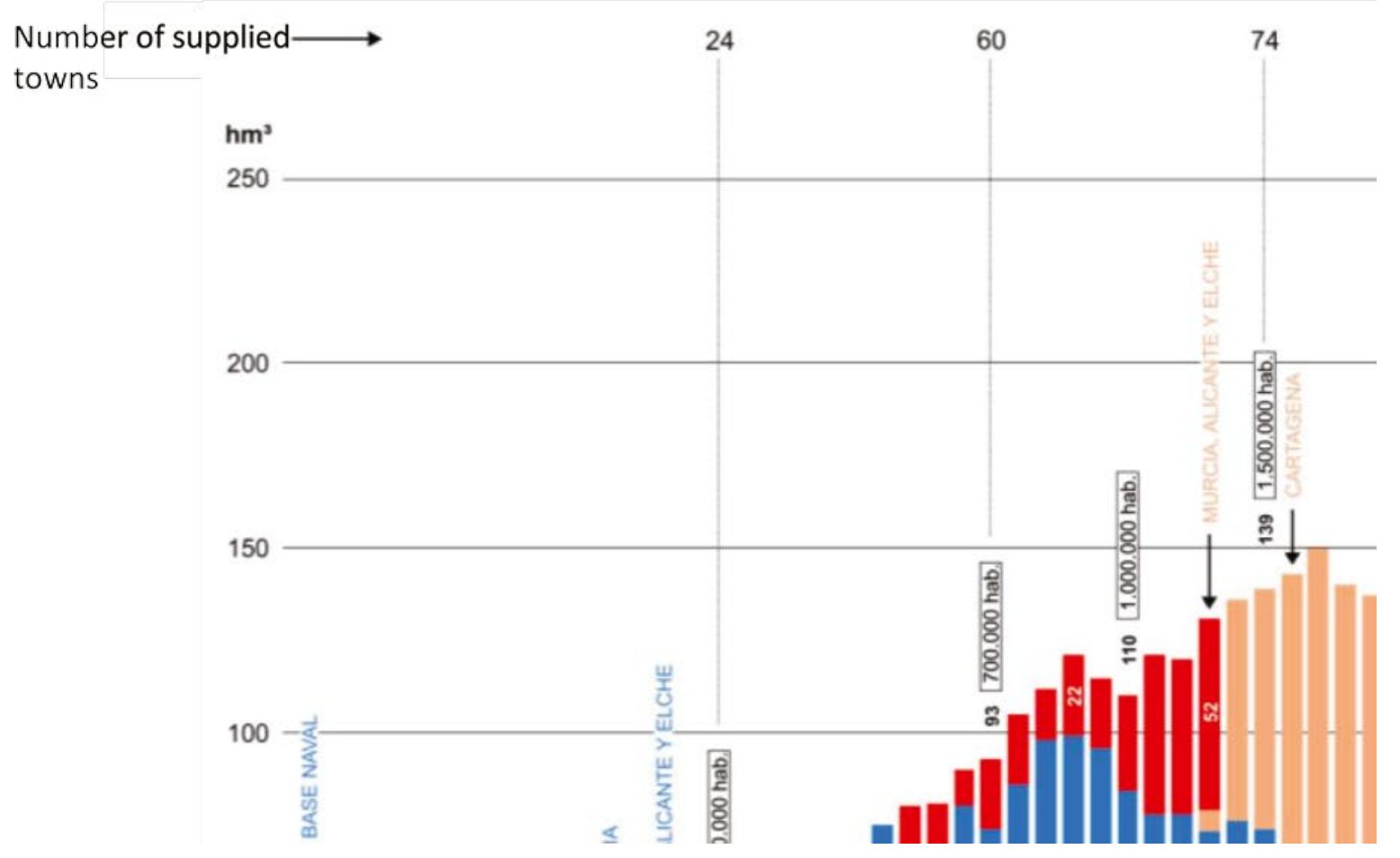

Figure 5 : Resources used by "Mancomunidad de Canales del Taibilla" (MCT, 2013).

Publicas" (CEDEX). Laboratory tests and simulation models have been performed to limit the range of salinity that could be reached in the areas near these meadows. Thresholds for the location of concentrate discharge and the design of pipeline seawater outfalls have been established.

Therefore, most of the problems, although not entirely resolved, have been mitigated. Consequently, in areas where desalination is not the only water source, and during wet periods, water supplied from desalination plants is replaced by other sources, the major obstacle to overcome has a name: integration. This is not needed if the water produced by a desalination plant cannot be replaced by traditional sources. In that case operation is guaranteed. But being a part of a general system of water resources, it must be integrated in that system in order to meet the aforementioned objectives, which, although complementary, are no less important. It should not be considered an isolated, back-up water source, but rather a vital complementary supply. For such purpose, environmental education is essential. The "Mancomunidad de Canales del Taibilla", an autonomous, although public body, is a good example. Figure 5 shows the evolution of the water resources used through time, with desalinated water as an additional component, integrated as a natural source of the whole system. This is the way to be followed.

\section{CONCLUSION}

Desalination in Spain has been, is and will continue to be an important source of water, particularly in drier regions such as the south-eastern Mediterranean area and the eastern Canary Islands. It underwent steady growth until the AGUA
Program burst onto the scene as an alternative to the Ebro Diversion. Although there is still collateral damage, such as the lack of complementary works (a result of the haste) and the isolation of some of the new plants which should be integrated in the joint resource management systems, the passing of time has normalized this situation. It has proved its essential role during dry periods and has also proved that costs continue their downward trend, which are key arguments for full acceptance of desalination.

The falling costs are a consequence of advancements in membrane technology. And with new technological innovations there is still margin for improvement. Nevertheless, despite the cost reductions of desalination and control of its environment impact, Spain must focus its efforts on full integration of the existing desalination plants operating in areas where traditional sources can be used in wet periods, because during these periods, desalination plants must operate as well. In order to make integration easier, progress must be made on cost recovery of these resources, even including environmental charges on over-exploited aquifers.

Except in some specific cases, building large new plants does not appear to be necessary. The high dependence of desalinated water production costs on the price of energy (improvements could reduce this but not avoid it) and on the workload at plants, mean that any plans for mass growth of this resource should be gradual and prudent, undoubtedly the main lesson learned from the Spanish experience. Last but not least, raising public environmental awareness and education, to accept desalinated water over costs as a new insurance that guarantees the supply in drought periods and the environmental benefits at any time, is crucial. 


\section{REFERENCES}

Cabrera E., Pardo M.A., Cabrera E. Jr. And Arregui F.J. (2013) - Tap water costs and service sustainability. A close relationship. Water Resources Management, Volume (27), Issue 1, 239-253.

CAla A. (2013) - Spain's Desalination Ambitions Unravel. The New York Times, October 2013. Special Report: Business of Green.

CEH (Centro De Estudios Hidrográficos) (2017) - Informe de Evaluación del Impacto del Cambio Climático en los Recursos Hídricos y Sequías en España (2015-2017), Madrid.

EC (European Commission) (2016) - Energy prices and costs in Europe. Report from the Commission to the European Parliament, the Council, the European Economic and Social Committee and the Committee of the Regions. Brussels 30.11.2016.

EUREAU (2017) - Europe's water in figures. An overview of the European drinking water and wastewater sectors. 2017 edition. The European Federation of National Water Associations.

LAPUENTE E. (2012) - Full cost in desalination. A case study of the Segura River Basin. Desalination, 300 (2012), 40-45.
MCT (Mancomunidad de los Canales del Taibilla) (2013) - Gestión del servicio 2013. Ministerio de Agricultura, Alimentación y Medio Ambiente. MAC. Cartagena (Murcia).

RuIz N. (2005) - La salinidad del agua de riego y del suelo. IFAPA Centro Alameda del Obispo, Consejería de Innovación, Ciencia y Empresa. Junta de Andalucía. Sevilla.

Torres M. (2008) - Evolución de los procesos de desalación en España. Libro La desalación en España. Aguas de la Cuenca Mediterránea, 2008. Depósito legal: M-27347-2008. Madrid., I, 81-113.

UrreA, M (2007) - Notas sobre tecnologías y costes de la desalación. Comunicación personal.

ZARzo D. (2013) - Campos E. y Terrero P. Spanish experience in desalination for agricultura. Desalination Water Treat. 2013 , 51, 53-66.

ZARzo D. (2017) - La desalación española, ejemplo mundial. Retema, 202 septiembre/ octubre, 2017.

Zarzuela A. (2018) - Desalinización y consumo energético. Conferencia AQUAEnergy: de la huella del carbono a la huella hídrica. Fundación Jorge Juan. Madrid, Noviembre 2018. 